\title{
Valid trust declarations over property not owned by the settlor or over unascertainable property
}

Article

Accepted Version

Wilde, D. (2020) Valid trust declarations over property not owned by the settlor or over unascertainable property. Trusts and Trustees, 26 (2). pp. 168-175. ISSN 1363-1780 doi: https://doi.org/10.1093/tandt/ttz136 Available at https://centaur.reading.ac.uk/88622/

It is advisable to refer to the publisher's version if you intend to cite from the work. See Guidance on citing.

To link to this article DOI: http://dx.doi.org/10.1093/tandt/ttz136

Publisher: Oxford University Press

All outputs in CentAUR are protected by Intellectual Property Rights law, including copyright law. Copyright and IPR is retained by the creators or other copyright holders. Terms and conditions for use of this material are defined in the End User Agreement.

www.reading.ac.uk/centaur

\section{CentAUR}


Central Archive at the University of Reading

Reading's research outputs online 


\section{Valid trust declarations over property not owned by the settlor or over unascertainable property}

\section{Introduction}

This article will suggest that, contrary to an apparently widespread belief, it is sometimes possible for a settlor to make a valid declaration of trust over property that, at the time of the declaration, is not owned by the settlor; or is unascertainable. ${ }^{1}$ These are two categories of property that raise similar, but not identical, issues. It is perhaps helpful to describe each category at the outset. First, property not owned by the settlor. The instance most familiar to lawyers is declarations of trust over property the settlor merely hopes, at the time of the declaration, to acquire in the future - a hope that may or may not later materialise - usually referred to as a declaration of trust over 'future', or 'after-acquired', property; or over a mere 'expectancy'; or over, in the case of a hope of inheriting property from someone at their death, a mere 'spes successionis' (hope of succession) or 'spes'. ${ }^{2}$ However, the category is wider than this: it includes property the settlor has no anticipation of owning and never does own; and it includes property that may not yet exist at all. In sum, this category extends to any property not owned by the settlor at the time of declaring the trust over it. The second category is unascertainable property: meaning property which - while the settlor may own it - cannot be identified from the settlor's description of it in the declaration.

Substantial discussion of these matters is usually limited to saying that a settlor cannot declare a trust over future property; nor over unascertainable property. Sometimes these propositions are - wisely - qualified by the word 'immediate': a settlor cannot declare an immediate trust over such properties. ${ }^{3}$ It will be suggested here that confusion is caused by the wider, unqualified statements - omitting the word 'immediate'.

Difficulties seem principally to arise from a failure to distinguish between the two basic ways in which a settlor may create an express trust. The settlor may make a 'self-declaration' of trust: that is, the settlor declares that s/he holds the property on trust personally. Or, the settlor may 'declare and constitute': that is, the settlor declares that some other nominated trustee, or trustees, will hold the property on trust, and constitutes the trust by vesting title to the property in them. ${ }^{4}$

\footnotetext{
${ }^{1}$ It will consider only the simple case of declarations of trust made purely by a settlor's voluntary choice: excluding the complications that arise when a contract or covenant to settle is enforceable against the settlor.

${ }^{2}$ Such future property must be distinguished from an existing right to the future enjoyment of property. For example, if $\mathrm{A}$ is holding assets on trust for $\mathrm{B}$ for life, remainder to $\mathrm{C}$, then although $\mathrm{C}$ will not receive the benefits of the trust assets until the end of B's life interest, C already has an existing property right: C's 'remainder interest' is a currently existing right to the future enjoyment of the trust assets, a right that they can sell, give away, pass by inheritance, etc, like other property. $\mathrm{C}$ could clearly declare they are holding their remainder interest on trust (a sub-trust) for D: it is property C currently owns.

${ }^{3}$ Admirably qualified statements can be found in Ben McFarlane and Charles Mitchell (eds), Hayton and Mitchell: Text, Cases and Materials on the Law of Trusts and Equitable Remedies (14th edn, Sweet \& Maxwell 2015) paras 2.082 (future property) and 4.071 (ascertainment).

${ }^{4}$ For the situation where the settlor declares s/he will be one of a body of trustees, see $T$ Choithram International SA v Pagarani [2001] 1 WLR 1 (PC), esp 11-12.
} 


\section{Self-declaration}

Looking first at self-declarations of trust: that is, the settlor declares that s/he holds the property on trust personally. The law here seems to be tolerably clear and agreed.

\section{Property the settlor does not own}

It is simple logic that a settlor cannot make an effective declaration that they are holding on trust, with immediate effect, property they do not own. Even if they expect to acquire that property in the future, this can make no difference to the current position: you simply cannot effectively declare that you are holding on trust now property you are not yet holding at all. The real question is how the law should respond if the settlor later does acquire that property: should the earlier declaration of trust be regarded as binding once the property is acquired? The law's answer is 'no'. Re Ellenborough ${ }^{5}$ is usually cited as authority for this proposition. The case does not directly decide this, but can fairly be taken as establishing the point by analogy. In that case, a settlor purported to transfer to trustees, on a declared trust, any property she might inherit from her brother if he died. This was, of course, an ineffective transfer: you cannot transfer what you do not yet have. At this point, the settlor had only an expectation she might inherit from her brother: she had not yet acquired any property from him. When the brother died, it was held the settlor was entitled to refuse to transfer the property she inherited to the trustees. So, by analogical extension, if she had made an ineffective self-declaration of trust (instead of an ineffective transfer into trust), on acquiring the property she would not be bound by the purported self-declaration of trust (just as she was not bound to make good the purported transfer into trust). ${ }^{6}$

This seems reasonable. We do not impose trusts on people without good reason. For a settlor acting purely voluntarily, creating a trust is a matter of choice. The settlor's initial declaration is, inevitably, a nullity; and the settlor might have changed her mind about the trust by the time she acquires the property. There is no reason to assume her continuing intention that the trust should exist; and certainly this cannot be inferred simply from the settlor accepting title to the property when it comes her way. If she does then still wish to establish the trust, she can. Re Northcliffe ${ }^{7}$ shows that if a settlor does choose to recognise a trust they have previously declared over property they did not own, once they have acquired the property, the trust will be effective. A settlor declared that he would hold on trust certain lands that he might afterwards acquire. He did later acquire such lands. He subsequently executed a will that stated he was holding the properties subject to the trust. It was decided that he, indeed, held the properties on trust. Russell J said: ${ }^{8}$ 'It was said that a will was an ambulatory document, but in my opinion any clause may be referred to in order to prove a fact, and I am satisfied that when the testator executed his will he recognized, and stated as a fact, that he held the Kent freeholds upon the trusts of the settlement.'

The court did not have to confront the tricky question of when the trust came into existence: whether the will was a new declaration of trust, creating a trust from the moment of its signing, or whether the statement in the will retrospectively confirmed that a trust had existed since the prior acquisition of each property. It is suggested that the law must be looking for a re-declaration here; and a trust can only exist from that point forward. The original declaration is a nullity. Once the settlor receives the property, a mere intention to hold on the previously declared trust cannot be seen as an affirmation of that trust: a mere intention to hold

\footnotetext{
${ }^{5}$ [1903] 1 Ch $697(\mathrm{Ch})$.

${ }^{6}$ And that was directly so decided in Williams v Comr of Inland Revenue [1965] NZLR 395 (NZ CA), 401.

${ }^{7}$ [1925] Ch $651(\mathrm{Ch})$.

8 ibid 654
} 
on trust, unexpressed, does not create a trust. ${ }^{9}$ And even acting in accordance with the previously declared trust may not be sufficient to amount to an affirmation by conduct: it is consistent with a mistaken belief by the settlor that they were bound by the previously declaration of trust - acting in a mistaken belief that one is bound by an obligation does not, on its own, create that obligation. ${ }^{10}$ The law must be looking for an expression of a wish to be bound by the trust: a re-declaration - and one cannot declare retrospectively that one has been holding on trust. ${ }^{11}$

\section{Unascertainable property}

With regard to unascertainable property, the position seems to be the same. Logically, what cannot be identified cannot be made the subject of an immediate legal obligation under a trust. For example, Hemmens $v$ Wilson Browne ${ }^{12}$ shows a self-declaration of trust over an abstract amount of money, without stipulating a specific fund, cannot create a trust: I cannot declare a trust over ' $£ 10,000$ ', but I can declare a trust over the $£ 10,000$ in a specified bank account. It would seem such uncertainty can only be overcome by the settlor choosing to appropriate property to the trust, and manifesting that choice - in effect a re-declaration of trust - which can only operate from that moment forward, not retrospectively.

\section{Declare and constitute}

Turning now to the declare and constitute mode of trust creation: that is, the settlor declares that some other nominated trustee, or trustees, will hold the property on trust, and constitutes the trust by vesting title to the property in them. This is where, it is suggested, confusion creeps in: from inappropriately copying across rules from the self-declaration situation to the declare and constitute situation.

\section{What 'seems obvious'}

Before looking at case law, I will start on extremely dangerous ground - that is, a consideration of what I feel seems obvious. Suppose, scenario (1), I declare that I will transfer the $£ 10,000$ in a specified bank account to a trustee on Friday and they are to hold it on a stated trust, which they agree to. When I transfer that money to the trustee on Friday, I take it as obvious that it is now held on the trust.

But suppose instead, scenario (2), I declare that I will transfer $£ 10,000$ - as only a stated amount - to the trustee on Friday and they are to hold it on the trust, which they agree to. Surely when I transfer that sum to the trustee on Friday, it is held on the trust - regardless of the fact that I might have made the transfer from one of several accounts, so that it was unascertainable property at the time of declaration, and only ascertained at the point of constitution? And suppose, further, scenario (3), I waited, as planned, until my monthly salary was received on the Friday and made the transfer out of those funds. Surely again the trust is established regardless of the fact that this was property not owned by me at the time of declaration, but only at the point of constitution? It seems obvious that in the 'declare and constitute' situation it must be possible to make a perfectly valid declaration of trust in respect of unascertainable property and/or property not owned - albeit that, as usual, there cannot be a subsisting trust until the moment of constitution (and, as usual, the settlor has the option to withdraw from the

\footnotetext{
${ }^{9}$ In Re Vandervell's Trusts (No 2) [1974] Ch 269 (Ch) (revd [1974] Ch 269 (CA)), Megarry J famously said (294): 'Normally the mere existence of some unexpressed intention in the breast of the owner of the property does nothing: there must at least be some expression of that intention before it can effect any result. To yearn is not to transfer.'

10 The 'settlor' in Williams $v$ Comr of Inland Revenue, above n 6, had acted on his mistaken belief that he had created a trust by paying over the money (see the report in the court below [1964] NZLR 996), but ultimately found to his cost, for tax purposes, that there was no trust.

${ }^{11}$ Ong v Ping [2017] EWCA Civ 2069, [2018] WTLR 1365, [53].

12 [1995] Ch 223 (Ch), 226.
} 
arrangement until that time). We could say that in all three scenarios, I made a renewed implied declaration at the moment of transfer - but this would be rather artificial. It is true that I manifested a continuing intention that the trust should come into existence, but that is as far as we can go: this was declaration followed by constitution.

The point is all the clearer when it is appreciated that, technically, scenarios (1), (2), and (3) all involved declaring a trust over property that the settlor never owned at any time. A transfer from one bank account to another legally involves exchanging, through the banking system, one item of property for another: the credit balance in the settlor's account is a chose in action the settlor holds against their bank; and after the transfer, this has been exchanged for a credit balance in the trustee's account amounting to a different chose in action they hold against their bank. ${ }^{13}$ This was property the settlor did not own at the time of declaration (or at any time), now being held on trust. ${ }^{14}$ And property that did not exist at the time of declaration cannot have been ascertainable property at the time of declaration, either.

Putting things another way, the transfer of money in scenarios (1), (2), and (3) was, as a matter of legal technicality, in effect, the settlor purchasing property in the name of the trustee (the settlor's original chose in action expended on purchasing the trustee's new chose in action). Purchase in the name of declared trustees, again, it seems obvious to me is a perfectly viable way of creating a valid trust. Let us spell out a purchase situation more clearly and make it scenario (4). This time, I declare that I will purchase described bonds in the name of the trustee on Friday and they are to hold them on the trust, which they agree to. Surely when I purchase such bonds in the name of the trustee on Friday, they are held on the trust - regardless of the fact that they were both property that I never owned and unascertainable property at the time of declaration?

\section{The disagreement}

All of this seems straightforward. ${ }^{15}$ But extremely eminent academics appear to disagree. So, seemingly, there are two views of the law here. For example, regarding scenario (2) it seems that Penner would question whether there was a trust. Writing in the context of secret trusts, he appears to say that, in the declare and constitute mode, a settlor cannot make a valid declaration of trust over property that, at the time of declaration, is unascertainable - regardless of ascertainment by the point of constitution. ${ }^{16}$ Regarding scenario (3) it seems that Critchley would question whether there was a trust. Also writing in the context of secret trusts, she appears to say that, in the declare and constitute mode, a settlor cannot make a valid declaration of trust over property that, at the time of declaration, is not owned by the settlor - regardless

\footnotetext{
${ }^{13}$ Foskett v McKeown [2001] 1 AC 102 (HL). Lord Millett, delivering the leading judgment, said (127-28): 'We speak of money at the bank, and of money passing into and out of a bank account. But of course the account holder has no money at the bank. Money paid into a bank account belongs legally and beneficially to the bank and not to the account holder ... There is merely a single debt of an amount equal to the final balance standing to the credit of the account holder.'

${ }^{14}$ Notions of tracing from one account into the other seem to have no place here. The law recognises tracing of a continuing title to property: but here title to the property has been parted with outright.

15 Although note that in all of these scenarios, it was stipulated that the trustee was expecting to receive the property on the declared trust. It is not essential that a trustee consent in advance to hold on a trust, but here it sets a context in which the settlor's subsequent transfer is obviously to be understood as intended by the settlor as constitution of the declared trust - the settlor would see it as the clear consequence of the transfer that the trustee would implement the trust. If, instead, for example, the settlor had declared only to their spouse an intention to transfer a sum on trust to the family solicitor, the solicitor being wholly unaware of the matter, a subsequent transfer of that amount to the solicitor, still unexplained to the solicitor, is not necessarily manifesting an intention to constitute the trust: the settlor may have changed their mind about the trust, and may simply want the sum held by the solicitor to the settlor's order - which the presumption of resulting trust would ensure.

${ }^{16}$ JE Penner, The Law of Trusts (11th edn, OUP 2019), para 6.63: although his central point, that secret trusts are testamentary, and the 'dehors the will' theory untenable, seems clearly right.
} 
of ownership by the point of constitution. ${ }^{17}$ Regarding scenario (4) it seems that Mee would question whether there was an express trust created. Writing in the context of resulting trusts, he appears to say that, in the declare and constitute mode, a settlor cannot make a valid express declaration of trust over property that is subsequently purchased in the name of the trustee, because it was not owned by the settlor at any time. ${ }^{18}$ (And this is, indeed, corroborated by a surprising absence of discussion in the books of purchasing property in the name of trustees as being a recognised method of constituting a declared trust. This omission may be because of the canonical status traditionally accorded to Turner LJ's list of three ways of giving - by outright gift, by transfer to trustees, and by a self-declaration of trust - in Milroy $v$ Lord. ${ }^{19}$ Books have regularly adopted this list as a framework for considering constitution of trusts, and since the judge spoke about 'transfers' to trustees rather than vesting property in trustees more widely, vesting by purchase in the name of trustees has in consequence been neglected. Also, in situations where it is clearly expressly declared that property to be purchased is to be held on trust, followed by purchase in the name of the trustees, problems tend not to arise: litigation tends to arise in cases where it is disputed what the circumstances of the purchase were - with such cases in consequence being discussed in sections of books dealing with the presumption of a purchase-money resulting trust, or the presumption of advancement, and rebuttal of these presumptions.)

Even regarding scenario (1), it is called into question whether a trust is created: and this is done even in the case of a simple transfer of property from settlor to trustee to constitute an already declared trust that does not involve property undergoing legal transubstantiation in the course of transfer, as money in a bank does. Hanbury and Martin ${ }^{20}$ a highly respected textbook, cautiously asks, ${ }^{21}$ 'Is it necessary that the conveyance and the declaration be contemporaneous? ... May X create a trust for B by declaring that $\mathrm{A}$ is to hold on trust for B; and later convey Blackacre to A?' - before eventually answering uncertainly, ${ }^{22}$ 'There appears to be nothing intrinsically wrong in holding that the declaration of a trust may precede its constitution ...'

\section{Case law authority}

The views of these academics do find support in the case law. ${ }^{23}$ On the other hand, there is also clear authority against them. A trust in scenarios (2) and (3) is supported by Re Bowden. ${ }^{24}$ This case appears to decide it is perfectly possible for a settlor to make a valid declaration (now) that trustees are to receive described property on trust, even though the settlor does not own it, and it is unascertainable, and to then (later) validly constitute the trust by getting title to that property to the trustees, without the need for any further declaration. The settlor, in 1868, (about to enter a nunnery) empowered nominated trustees to receive any property she might inherit from her father at his death and declared a trust over such property. After her father died, in 1869 , the trustees collected what the settlor was left under her father's will and held it on the

\footnotetext{
${ }^{17}$ Patricia Critchley, 'Instruments of Fraud, Testamentary Dispositions, and the Secret Trusts Doctrine' (1999) 115 LQR 631, 634: although, again, her central argument - in line with Penner's - appears clearly right.

${ }^{18}$ John Mee, 'Presumed Resulting Trusts, Intention and Declaration' (2014) 73 CLJ 86, 110-11: although, again, the central points argued there are well made.

19 (1862) 4 De G F \& J 264, 45 ER 1185, 274.

${ }^{20}$ Jamie Glister and James Lee (eds), Hanbury and Martin Modern Equity (21st edn, Sweet \& Maxwell 2018).

${ }^{21}$ Para 5.001.

${ }^{22}$ Para 5.028.

${ }^{23}$ For example, Kaki v Kaki [2015] EWHC 3692 (Ch), [51], deciding a settlor's letter giving instructions for the beneficial interests in a lease subsequently purchased in the name of trustees could not have been a valid declaration of trust over it, because the lease did not yet exist; the judge also suggested it could not have been a valid declaration of trust over the purchase money, because no specific fund was yet ascertained.

${ }^{24}$ [1936] Ch 71 (Ch).
} 
declared trust. The settlor's claim, decades later, that there was no trust, so that she was personally entitled to the property, was rejected. Bennett $\mathrm{J}$ said: ${ }^{25}$

'Under a valid authority, unrevoked, the persons appointed trustees under the settlement received the settlor's interest under her father's will, and, immediately after it had been received by them, as a result of her own act and her own declaration, contained in the voluntary settlement, it became impressed with the trusts contained in the settlement.'

And a trust in scenario (4) is supported by Muggeridge $v$ Stanton. ${ }^{26}$ This case appears to show it is perfectly possible for a settlor to declare a valid express trust over property purchased in the name of trustees, despite the facts that the property was never owned by the settlor and was unascertainable at the time of the declaration, without the need to procure in the transfer of title a declaration of trust by either the vendor or the trustees. The settlor created a trust. It contained a provision that she could add income from the trust back into the trust fund. She used some trust income to buy consols in the names of the trustees without informing them; but she also used some other money to do the same. The Court of Appeal in Chancery held that all of the investments bought were subject to the trust. In respect of the money that was not trust income, the court held the settlor had effectively declared (by conduct) that the investments purchased in the names of the trustees with it were to be held on the same trusts. Lord Campbell LC, delivering the leading judgment, said: ${ }^{27}$ 'With regard to the surplus money... there was equally a declaration of trust with regard to the whole of the vestments (sic)., ${ }^{28}$

\section{Discussion}

It is submitted that this disagreement over the scope for validly declaring a trust over property the settlor does not own, or has left unascertainable, where the declaration is later effectively constituted, is not an issue to resolve by weighing the balance of authorities for and against. ${ }^{29}$ This should be decided by reason. In the case of a self-declaration of trust, it is a simple dictate of logic that a settlor cannot validly declare an immediate trust over property they do not own or have left unascertainable: one cannot hold on trust what one does not hold at all, or what cannot be identified. But when this proposition is copied across - losing the word 'immediate' - to the declare and constitute situation, its rationale disappears and it starts to look like merely an article of faith. There is no dictate of logic, nor any other apparent reason, to say a settlor cannot validly declare, for the future, a trust over described property they do not own or have left unascertainable, regardless of the fact that the settlor does later successfully constitute the declaration by vesting, through transfer to, or purchase in the name of, the trustee(s), the now ascertainable property. This would be a perfectly functional trust. The law is not there to make

\footnotetext{
25 ibid 75.

${ }^{26}$ (1859) 1 De G F \& J 107, 45 ER 300. The view in some books that this situation involves a presumed rather than express trust, based on Re Curteis' Trusts (1872) LR 14 Eq 217, has been pronounced incorrect: Gany Holdings (PTC) SA v Khan [2018] UKPC 21, 21 ITELR 310, [17]-[20]. An express trust in this scenario was endorsed by Lord Upjohn, delivering the leading judgment, in Vandervell v IRC [1967] 2 AC 291 (HL), 313.

27 (1859) 1 De G F \& J 107, 45 ER 300, 118.

${ }^{28}$ Indeed, purchase in the name of trustees must be a regular method of establishing trusts. For example, Kaki $v$ Kaki, above n 23, seemingly upheld a declaration of trust over a lease purchased in the name of trustees, which the settlor never owned (upheld because of oral statements at the time of purchase, repeating the earlier letter, which had been held not to count as a valid declaration). The declaration could be interpreted instead as over the purchase money, which was owned by the settlor, which then traceably went into the lease: but that would be both artificial and inconsistent with the court's treatment of it as a declaration of trust over land, needing to comply with Law of Property Act 1925, s 53(1)(b) (for which the earlier letter supplied signed written evidence: [2015] EWHC 3692 (Ch), [53]).

${ }^{29}$ Doubtless other authorities can be cited in each direction.
} 
trusts fail for purely dogmatic reasons. As Gardner has pointed out, the law of trusts is fundamentally a 'facilitative project' for settlors. ${ }^{30}$

There may, however, be a distinction between property the settlor does not own, on the one hand, and property the settlor has left unascertainable, on the other hand - regarding the time by which the problem (lack of ownership or unascertainability) must be resolved. In the case of property the settlor does not own, it seems logically necessary that the problem must be overcome by the time of vesting the property in the trustee(s), either by the settlor acquiring the property and transferring it to the trustee(s), or by the settlor purchasing the property in the name of the trustee(s). However, it is not clear that a problem of unascertainability needs to be cured by the time the property is vested in the trustee(s). In principle, it seems arguable that the law should only require ascertainability by the date the trust comes into operation - which may be a later date. In particular, there appears to be scope for vesting assets in the trustee(s), with a trust to affect only a fraction of them, a fraction to remain unascertainable until later, ascertainment to be possible only when the trust is to arise. That is, the sort of 'floating trust' sometimes suggested. ${ }^{31}$

\section{Self-declare and self-constitute}

A variation on the self-declaration model, and the declare and constitute model, is possible. A settlor may declare that they will hold on trust property that they propose to go out and acquire for the purpose: self-declaration, with self-constitution by acquisition. This declaration will inevitably be over future property and may relate to unascertainable property. It is suggested that the self-declaration rules should govern this situation. The fact that the settlor goes out to acquire the described property does not, on its own, demonstrate a continuing intention to constitute the trust - in the way that vesting the title to the property in another trustee would. The settlor may have decided to acquire the property beneficially for other purposes. The law should require an affirmation of the trust by the settlor after acquisition of the property before such a trust is regarded as established.

\section{Conclusion}

It is a dictate of logic that a settlor cannot validly make a self-declaration of an immediate trust over property they do not own and/or have left unascertainable: one cannot hold on trust what one does not hold at all, or what cannot be identified. But this proposition is sometimes inappropriately copied across - abandoning the word 'immediate' - to the situation where a settlor declares that some other nominated trustee(s) will receive described property on trust. In this situation, there is no dictate of logic, nor any other apparent reason, to say a settlor cannot validly declare (now) that a trust is to exist over described property they do not own and/or have left unascertainable, if the settlor does (later) successfully constitute the declaration by vesting such described property, through transfer to, or purchase in the name of, the trustee(s), such that the trust property is ascertainable by the time the trust is to come into operation. This is a perfectly functional trust and its declaration was valid, despite the fact that,

\footnotetext{
${ }^{30}$ Simon Gardner, An Introduction to the Law of Trusts (3rd edn, OUP 2011), ch 2.

31 Ottaway v Norman [1972] Ch 698 (Ch), 713 (Brightman J, obiter, in the context of secret trusts): see David Hayton, 'Ottaway v Norman' (1972) 36 Conv 129 (note). JE Penner, The Law of Trusts (11th edn, OUP 2019), para 7.66, suggests floating trusts are generally unnecessary because a legal solution is already available in the form of a conventional trust, with life interest and remainder interest, to accommodate what testators want in the typically problematic gift of, 'to X but what is left at their death to go to Y'. However, this solution only works if it corresponds to the sort of 'floating' arrangement desired. For limitations on the possibility of floating trusts, see Robert Stevens, 'Floating Trusts' in Paul S Davies and James Penner (eds), Equity, Trusts and Commerce (Hart 2017), ch 5, discussing Re Lehman Bros International (Europe) (No 4) [2010] EWHC 2914 (Ch) and [2011] EWCA Civ 1544, [2012] 2 BCLC 151.
} 
at the time of the declaration, the property was not owned by the settlor and/or was unascertainable. 